\title{
Effective Strategies of Professional English Teachers Development in Higher Vocational Colleges
}

\author{
Liailun Chen \\ Wuhan Technical College of Communications, Wuhan, Hubei, 430065
}

\begin{abstract}
Teachers 'professionalization has become the main trend and trend of teachers' career development. By discussing the professionalization of teachers and higher vocational education, this paper discusses the professional connotation of public English teachers in higher vocational colleges and the ways of their development. It can be used as a reference for vocational English teachers Teachers' professional development to provide theoretical basis, enrich the connotation of professional development of teachers, so as to become teachers of public English teachers to provide a theoretical basis for professional and sustainable development ideas.

Keywords: Higher Vocational Colleges, Professional English Teachers
\end{abstract}

\section{Introduction}

The professional development of teachers has been raised since the 60s of last century, causing great concern to the education sector related personnel. Teachers' specialization has become the main trend of teacher development. The professionalization of teachers can not only improve the quality of teaching, but also can improve the professional status of teachers. Teachers' professional development needs the continuous development of teachers themselves and external support system to protect. Although the state put forward the development of vocational education, but for higher vocational colleges, capital investment is relatively limited, especially in the implementation of student funding system, vocational colleges in order to expand students, can only be 
limited funds first to training base And enhance the practical ability of professional teachers, and expand its advantages of professional attraction and social influence. As an important part of the public basic courses in higher vocational colleges - English courses, but facing the risk of marginalization.

\section{Teachers' Status Quo of Public English Teachers in Higher Vocational Education}

The results show that the knowledge of pedagogical psychology and other related theoretical knowledge is not enough. $17 \%$ of the teachers have a good grasp of pedagogy, psychology and other related theoretical knowledge, and can be applied to teaching practice, $66 \%$ of teachers can grasp the basic knowledge of pedagogy psychology theory, and $17 \%$ Not understanding the relevant theory, resulting in teaching can not be effectively implemented in accordance with their aptitude, affect the teaching effect, which is not part of the teachers of educational psychology related to the theory of education is positively related to learning. The survey also reflects Sun Ran most teachers of English teachers to accept teacher education, to understand the relevant pedagogy, psychology knowledge, but to be effectively applied to the teaching practice, the teacher education phase of teaching theory related training is still insufficient .

About the mastery of linguistic theoretical knowledge, $75 \%$ of teachers understand the general level, there are $25 \%$ of teachers do not understand. Linguistics in cognitive linguistics, applied linguistics, social linguistics, pragmatics and other theoretical knowledge will affect the teachers in teaching whether the flexibility to use the appropriate teaching method. Linguistic knowledge and educational psychology theoretical knowledge is the basis for teachers in the teaching of scientific research, is a prerequisite for teachers to carry out scientific research. About the mastery of English language knowledge, which is the teaching of public English teachers ontology knowledge, $83 \%$ of teachers are well grasped, there are still $17 \%$ of teachers to master the general level, which is bound to limit the depth of teaching teachers and Breadth. About the mastery of English knowledge in the industry, only $33 \%$ of the teachers generally understand, $67 \%$ of the teachers know very little, which is currently in vocational English teaching a major problem. Industry English (ESP) is a "teaching requirements" module, the inevitable trend of the development of English teaching in higher vocational colleges. Industry knowledge of English is imminent. The general knowledge of the degree of social knowledge related to English proficiency is general. Language teaching is inseparable from the community, is inseparable from the culture, knowledge of teachers is extensive, profound, the information age of the latest knowledge of the society to grasp the application, are excellent teachers are essential. 


\section{Analysis on the Problems of the Professional Development of Public English Teachers in Higher Vocational Colleges}

However, when we evaluate the teachers, the academics seem to be exclusive of the scientific research results, and the teaching and application are often excluded. Often, the amount of scientific research is the criterion for the evaluation and promotion of the teachers' professional titles, and the teaching and scientific research are the two major tasks of the teachers. Resulting in many teachers are tired of published papers, monographs, to meet the low level of repeat operations, it is difficult to have innovation. In addition, research can be used as an effective means of propaganda schools, but the teaching effect can not be immediate. The teaching of public English teachers is more important than that of advanced education. The theory and practice can not be carried out in two legs, which leads to the separation of teaching and scientific research, and both sides can not make effective achievements.

This is inseparable from the heavy education, research environment, resulting in many teachers regardless of personal professional development, blindly reach the required qualifications, certificates and other rigid standards. For example, some teachers regardless of what professional first became a graduate student or doctoral students on the line.

At present, higher vocational colleges basically use unified national planning teaching materials, their teaching materials are updated slowly, and they still stay in the basic skills of improving the students' listening, speaking, reading and writing, and can not fully reflect the vocational English class. In addition, vocational English courses as an application-oriented curriculum, in addition to improving students' ability to communicate in English, able to deal with the future of English-related business-related business capabilities, but also for students to lay the foundation for industry English learning. However, due to the long-term professional barriers, the lack of dialogue between subjects, resulting in public English teachers can not do the teaching of English industry, vocational schools and students of English language proficiency requirements do not match.

\section{Professional Development of Public English Teachers in Higher Vocational Colleges}

The teachers of higher vocational English should set up corresponding curriculum objectives, teaching contents, training objectives and evaluation system according to the personnel training system and objectives of higher vocational education. Reform teaching method, perfect practice, individualized teaching, promote professional education and innovation and entrepreneurship education organic integration. The teaching effect should be rethought, and the student-centered teaching and research should be carried out in the aspects of professional construction, curriculum reform, practical teaching and lifelong learning, so as to improve the teaching ability and level of scientific research. The professional 
teaching of general higher education is a complete framework of the vertical curriculum system, and higher vocational education based on the work process of the horizontal module based teaching, emphasizing the professional orientation and application-based. Therefore, vocational English teachers are in addition to professional curriculum knowledge, industry knowledge, vocational education, knowledge, but also a deep knowledge of the humanities. "Complex" teachers should highlight the following qualities: a solid level of professional knowledge; good communication, coordination and organizational capacity; economic globalization, the information society to guide the ability to advance with the times of innovation. Teachers need to change their role, from knowledge disseminators to intelligent developers, from knowledge producers to knowledge innovators and the transformation of the results of the "birth of those."

In the Era of Knowledge Economy, Teachers of Public English in Higher Vocational Education Should Set up the Concept of Lifelong Education. Under the background of combining work with study and cooperation between colleges and enterprises, public English teachers in higher vocational colleges should change their concepts, advocate scientific spirit and set up lifelong learning concept, always adhere to student-oriented, pay attention to teaching methods and means, and pay attention to the link of teaching. Mutual promotion, increase the integration of teaching reform, integrating the concept of integration of production and education throughout the work of all aspects of personnel training. Teachers 'morality is the most important quality of teachers and the soul of teachers' profession. Lide first set up the division, the tree is the first person, and constantly improve their own moral qualities, in order to enhance the status of teachers, access to social recognition and respect. Teachers should uphold the cause of loyalty, care and understanding of students, the work of enthusiasm, with professionalism, and continuously enhance the professionalism of consciousness.

Focusing on the induction training phase of adaptation and focusing on the enhanced on-the-job training phase. Vocational schools can learn from the successful professional development of teachers in the training experience. In the teacher training, to take personalized, targeted training, in addition to professional training, teaching theory, method training, but also need to focus on teacher education philosophy, career planning and development, mental health, interpersonal and other aspects of quality improvement. To take the part of the burden of personal development costs of the way to stimulate teachers' initiative and enthusiasm.

Different objectives for the training of personnel, should be developed different standards of professional title. There should be some differences between the titles of teachers in vocational colleges and those in comprehensive universities. In the same way, the professional titles of professional teachers and general courses teachers in different vocational colleges should be different. Secondly, the importance of general courses in the "high-quality skilled personnel," the role of training objectives, to increase the teaching of public English courses, teachers, capital investment and training, quality teaching resources to promote the improvement of teaching methods and research projects 
and results produce. Encourage teachers to learn from or share quality information resources, will help their own development of advanced concepts and methods for their use, and further development in practice, can effectively avoid duplication of operations and improve efficiency.

\section{Conclusion}

Based on the existing theoretical research and drawing on the advanced experience of developed countries, this paper deeply analyzes the current situation of public English teachers' professional development in the light of the connotation and policy orientation of interpretation, the analysis of specialization status, the clarification of specialization goals and the construction of sustainable development strategy. The present situation and the specialization gap of public English teachers in higher vocational colleges in China, so as to put forward the corresponding solutions and explore the professional development approach of public English teachers in line with the status quo of higher vocational education. This study enriches the theory of teacher specialization, which provides the theoretical basis and the sustainable development idea for the teachers of public English to become professional teachers. At the same time, strengthening the professional study of public English teachers can enhance the systematic connotation of public English professionalization in higher vocational colleges, and make clear the direction of professional development and provide the train of thought for professional development and teaching reform of public English teachers.

\section{Acknowledgement}

Fund project: College Project of Wuhan Technical College of Communications: Research on Problems and Countermeasures of Vocational Public English Teachers' Professional Development (q2015006)

\section{References}

[1] Zhang Xiaozhu, Zhong Weihong. Exploring the Examination of Public English Course in Higher Vocational Education Based on Teachers' Autonomy [J]. Observice, 2016(11)

[2] Yi Yaqin. Application of professional competence-oriented teaching method of public English in vocational colleges [J]. Higher Vocational Education , 2016 (04)

[3] Wang Xiaoqing. Effective Ways to Ask Questions in College English Classroom Teaching [J]. China New Communication, 2016 (22)

[4] He Xun. Economic New Normal College English Teaching Reform [J]. Journal of Technology and Economy, 2016 (31) 